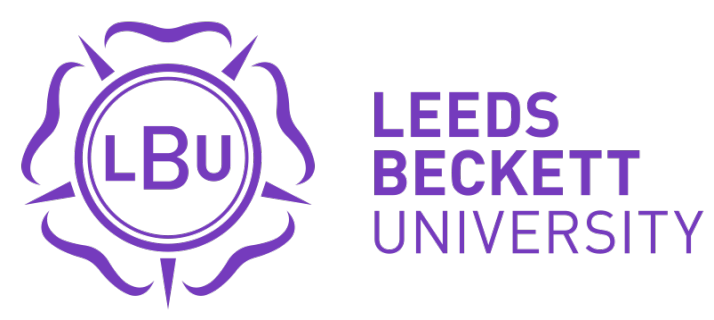

Citation:

Koens, $\mathrm{K}$ and Thomas, $\mathrm{R}$ (2015) Is small beautiful? Understanding the contribution of small businesses in township tourism to economic development. Development Southern Africa, 32 (3). 320 - 332. ISSN 0376-835X DOI: https://doi.org/10.1080/0376835X.2015.1010715

Link to Leeds Beckett Repository record:

https://eprints.leedsbeckett.ac.uk/id/eprint/1274/

Document Version:

Article (Accepted Version)

The aim of the Leeds Beckett Repository is to provide open access to our research, as required by funder policies and permitted by publishers and copyright law.

The Leeds Beckett repository holds a wide range of publications, each of which has been checked for copyright and the relevant embargo period has been applied by the Research Services team.

We operate on a standard take-down policy. If you are the author or publisher of an output and you would like it removed from the repository, please contact us and we will investigate on a case-by-case basis.

Each thesis in the repository has been cleared where necessary by the author for third party copyright. If you would like a thesis to be removed from the repository or believe there is an issue with copyright, please contact us on openaccess@leedsbeckett.ac.uk and we will investigate on a case-by-case basis. 


\section{Is small beautiful? Understanding the contribution of small businesses in township tourism to economic development}

Ko Koens and Rhodri Thomas

Ko Koens, Academy of Hotel and Facility Management, NHTV University of Applied Sciences, The Netherlands ko@kokoens.com

Rhodri Thomas, International Centre for Research in Events, Tourism and Hospitality (ICRETH), Leeds Metropolitan University, UK r.thomas@leedsbeckett.ac.uk 


\section{Abstract}

The increased importance attached by policy-makers to the anticipated developmental effects of tourism in developing countries has been insufficiently examined by academic researchers, particularly in the context of the contribution of small firms in urban areas. This deficiency is addressed by providing a review of existing research followed by an analysis of interviews with ninety tourism business located within and outside the townships of Langa and Imizamo Yethu, Cape Town, South Africa. The findings reveal tensions between the different actors involved in township tourism. While the involvement of small, locally owned, businesses is beneficial it is limited by conflicts of interest, lack of trust, limited social networks and little attachment to the township locality. The discussion highlights the complexity of tourism's role in economic development which has significant implications for local policy-makers.

Keywords: township tourism; small businesses; economic development; Cape Town; South Africa. 


\section{Introduction}

Increasingly portrayed as an essential part of tourism economies, small businesses attract widespread interest among policymakers in developing countries due to their perceived potential for local economic development (Rogerson 2005, Jaafar et al. 2011). Nevertheless, there is the suggestion that the importance of small tourism businesses for economic development is limited by 'the dominant power of multinational hotel chains and package holiday providers in tourism global production networks' (Christian, 2010 in: Saarinen et al. 2011: 201). Moreover, some commentators have observed that small businesses are represented in some policy discourses as backward, undynamic and a hindrance to innovation and growth (Thomas et al. 2011:1).

It is remarkable how much has been assumed, and how little has been demonstrated, with reference to the contribution of small tourism businesses to economic development in developing countries. As early as the 1980s, the potential benefits of small business ownership for local community development were already highlighted by academics critical of an over-reliance on large externally-owned enterprises (Britton 1982, Wahnschafft 1982). Since then, however, the role of tourism for poverty alleviation has received little attention and currently 'largely remains terra incognita among tourism academics' (Zhao \& Brent Ritchie 2007: 120). The existing literature dealing with small business involvement in tourism is equally scant and consists mainly of valuable but descriptive case studies (e.g. Booyens \& Visser 2010; Rogerson 2004a,b). Yet, as Scheyvens (2007:242) argues, to better understand the role of small businesses for local economic development there is a need for 'detailed studies of systems, processes, places and interactions between people'.

This paper responds to the current deficiency in the lietarture by examining small businesses involved in tourism within and outside the townships of Langa and 
Imizamo Yethu, Cape Town, South Africa. Following a systemctic review of existing literature and face-to-face interviews with ninety small business onwers, it discusses the complexity of tourism's role in economic development and reveals how small and larger businesses contribute to, as well as limit, local economic development.

\section{Local economic development and small businesses}

Although a universally agreed definition of local economic development remains elusive, there is some consensus that it incorporates a focus on a defined territory, as well as a concern for sustainable economic, social and ecological welfare (Rogerson \& Rogerson 2010:470). Small tourism business development fits with these overarching ideas in that they offer the prospect of utilising local resources and skills (Helmsing 2003) and provide 'significant and proven developmental benefits' for local communities (Scheyvens \& Russell 2012:418). Small business ownership is said to make it easier for local people to participate economically and take control over the development of tourism (Hampton 1998). Moreover, it enables greater self-reliance and dynamism in dealing with changing economic circumstances and makes owners less reliant on external actors (Poon 1990, Duval 1998). This resonates with one of the key features of local economic development, namely that it 'seeks to encourage growth and to diversify the local economic base into sectors that are usually quite different from those in which recent hardship has been experienced' (Binns \& Nel 2002:236).

It is also notable that less powerful groups in society, such as women or those with limited resources, that have difficulty becoming economically active in other sectors can potentially benefit from tourism (Milne 1998:41). The direct contact between hosts and guests that is common with small businesses limits the status gap between these two groups and allows for better embeddedness of tourism in local communities. The argument is that social networks and cohesion within 
communities can lead to more communal ownership and sharing of benefits: 'When resident people feel they exert control over tourism they are less likely to experience what others may see as negative social or cultural impacts' (Scheyvens 2008:132). Additionally, local ownership and control over tourism is seen by some to increase the likelihood that benefits stay within the local area and reduce economic leakages (Brohman 1996). In the hospitality industry small businesses are expected to source products locally, compared to larger counterparts, which are more likely to achieve economies of scale through contracts with suppliers from elsewhere (Scheyvens \& Russell 2012). Wilson (1997:63) went as far to say that the involvement of small businesses led to 'wide local ownership of resources and the broad distribution of benefits throughout the local community'.

The extent to which small tourism businesses inevitably make significantly positive contributions to local economic development is contested. Koens et.al. (2009), for example, demonstrate that, even if a destination is dominated by small businesses, it is difficult for policymakers to limit negative social and environmental sideeffects as tourist numbers grow. Indeed, the negative impacts of small businesses on the wider community may actually be greater than with larger enterprises as the more intensive contact with the local population makes it more invasive (Scheyvens 2008:133). Seen in this light, mass tourism provided for by mainstream enterprises has even been suggested as a more desirable option, as it can generate more material benefits and remain viable in a highly competitive economic environment (Thomlinson \& Getz 1996:197). Small tourism businesses may simply not be able to 'supply large-scale employment or a reliable stream of tax revenues to be used to implement beneficial government policies' (Burns 2004:25).

A different critique on small business development comes from those who have examined developments in the Gambia. There small craft vendors and tour guides have been termed a nuisance to tourists by some who have even accused them of making the destination less attractive to tourists (Bah \& Goodwin 2003). 
Additionally, Scheyvens \& Russell (2012:432) identified poor employment conditions among small businesses as a reason for the limited positive impact of small tourism businesses in Fiji. While these studies begin to reveal the difficulties of assuming that the promotion of small businesses for local economic development is inevitably desirable, the reasons underlying these issues remain largely unidentified.

In South Africa both small business development and local economic development are key aspects of official conceptualisations in the 'fight against poverty'. Since the end of apartheid, the South African government has sought economic growth which is seen as a proxy for development - and to redistribute wealth. Although redistribution and equality were watchwords initially, since 1996 the country has followed a neoliberal course to create wealth and, it claims, to fight poverty (Cheru 2001, Peet 2002, Dierwechter 2006:244). This change in policy made small businesses a key asset for poverty alleviation, job creation and the enhancement of national economic growth.

Support for small business has remained an important aspect of the policy discourse since the mid-1990s (Rogerson 2004c:765), as has the implementation of pro-poor local economic development (Nel \& Rogerson 2005). Current government thinking on Local Economic Development focuses on both poverty relief and economic growth. The devolution of authority and developmental leadership to local governments, as reflected in the country's commitment to 'developmental local government' has obliged local governments to seek innovative growth options and plug the employment gap, particularly in highly impoverished urban areas such as the townships (Binns \& Nel 2002). Increasingly, tourism is recognised as critical for the long-term development of its economy, with policies strongly targeted at increasing small business involvement (Rogerson 2012:204). The concept of 'responsible tourism', which is advocated by officials in South Africa, 
incorporates small businesses and is promoted actively via television commercials and local development forums (Harvey 2011:125-6).

\section{Small firms and tourism development}

The research reported here focuses on two townships near Cape Town, Langa and Imizamo Yethu, which are predominantly inhabited by Xhosa people and part of the rapidly growing township tourism industry. Although still viewed as a rather alternative form of tourism, an estimated $20-25 \%$ of all international tourists to Cape Town now book a township tour, which results in around 300,000 visitors annually, making the townships one of the most popular attractions in the region (Pirie 2007:235, Koens 2012). The development of township tourism into the mainstream can also be observed in the type of enterprises offering their services, particularly in tour operation. Until the early 2000s township tours were almost exclusively provided by locally owned tour operators. Since then large tour operators have taken a significant share of the market. This illustrates what Scheyvens (2008:133) found elsewhere, whereby 'there is... always the danger that what begins as an effective, locally based response to increasing demand for certain tourism experiences from intrepid tourists venturing off the beaten track will, as it becomes more successful, ...[is] ... taken over by outside interests'. An estimated $80-90 \%$ of the market share is now taken by five large tour operators that operate from outside of the townships, leaving the majority (40-60) of small tour operators to compete heavily for the remaining $10-20 \%$ of visitors (Koens 2014).

The competitive nature of the township tourism industry, combined with an uncertain social and business environment, has created a situation in which it is not self-evident that small businesses will contribute significantly to local economic development. To examine this issue, ninety tourism business owners located within and outside these townships were interviewed as well as twelve local 
policy-makers who are seeking to maximise the role of tourism in economic development. Analysis of these interviews suggests that there are four main factors that limit the potential benefits of small township tourism businesses. First, confirming earlier research in other destinations (e.g. Dahles \& Bras 1999, Van der Duim \& Caalders 2008), it is not axiomatic that small township tourism businesses will be able to attain market access and gain enough custom to prosper. Second, not all small business owners will grow their business and provide wider economic development; instead many do not get beyond subsistence. Third, the social cohesion and local embeddedness that are believed to underlie the wider sharing of small business benefits were not observed in the townships. A limited social cohesion and sense of place means individual business growth is targeted at the cost of wider local economic development. Finally and related to this, the economic benefits of tourism are increasingly concentrated with a few operators benefiting from the increased scale of tourist activity. Each of these will be discussed in turn below.

\subsection{Difficulties in getting market access}

Following apartheid tourism had the highest share of white business ownership of any sector in South Africa when apartheid ended (Rogerson2008a; 2008b). Even today, white-owned businesses that emerged during apartheid continue to dominate and control the industry and small township tourism business owners operate at a significant disadvantage with respect to the market power and economies of scale enjoyed by large tourism enterprises from outside of the townships (Rogerson 2005). Indeed, small tour operators highlight their inability to effect changes among actors in the dominant tourism industry outside of the townships. Nearly all have had at least one negative experience with staff at tourism information agencies, travel agents or hotels. These gatekeepers for independently travelling tourists are accused of corruption and demanding personal commission on top of normal local commission tariffs. While it was 
impossible to confirm the veracity of all accusations, they show the frustration of township tour operators in dealing with a powerful tourism industry. Experiences during the FIFA World Cup 2010 provide further illustration, where all transport capacity was signed off to 5 or 6 larger tour operators in the Cape Town area, who then distributed it among small tour businesses under such poor conditions that only few opted to get involved. The arrangement for accommodation businesses was similarly disadvantageous for small business owners in that it required businesses to sign off their entire capacity without any guarantee of business.

Examples such as these confirm imbalanced power relationships as a key problem for small businesses that try to get involved in tourism (Britton 1982, 1987, Kirsten \& Rogerson 2002). The stimulation of small business development, without consideration of how such businesses will get market access and gain custom, is therefore unlikely to lead to local economic development. A possible solution would be to stimulate direct market access for small township tourism businesses, as is advocated by government (Koens 2012). This might include creative uses of technology or brokerage of tours in hotels by intermediaries close to the businesses. However, such proposals may be difficult to implement because of the uncertain living and business conditions of the small business owners and the intense competition within the tourism industry.

\subsection{Lacking business growth in an uncertain environment}

Small township tourism business owners operate in a highly uncertain social and business environment. In both Langa and Imizamo Yethu nearly $50 \%$ of the population are unemployed or work informally (City of Cape Town 2013) with poor pay and little job security (Rolfe et al. 2010). Additionally, most live in a rented shack in the garden of a homeowner, in shanty dwellings, or, in Langa, in hostels where they share a room with multiple families in overcrowded conditions. Since these housing arrangements tend to be agreed upon without formal tenancy 
agreements, owners can be made homeless without much notice. In the shanty areas, fires also occur on a regular basis, displacing families and destroying possessions, including stock and supplies. When a fire swept across Imizamo Yethu township at the time of this research, two craft workers completely lost their supplies of paintings that they had been working on throughout the winter. The high levels of unemployment and poor living conditions in the townships are accompanied by high levels of crime. Although tourists are rarely targeted, small business owners and other township residents regularly fall victim to burglary or muggings. The lack of effective law enforcement, due to lack of capacity, corruption and the highly disorganised nature of the townships, further adds to this sense of uncertainty and insecurity.

Operating under such circumstances increases the importance of income security and nearly $60 \%$ of interviewed small business owners have multiple sources of income. The type of employment outside tourism varies from low skilled work such as cleaning or babysitting to professional occupations such as nursing and information communication technology (ICT) consultancy. This hinders their availability and makes them appear 'unreliable' in the eyes of enterprises from outside of the townships, which further limits trading opportunities. Furthermore, contrary to expectations of South African policymakers (Rogerson 2005), not all owners seek to grow the business. Instead, the majority focus upon survival and subsistence and are unwilling to risk investing strongly to grow their business. While it is true that the income from tourism is essential in helping individual families survive, in many cases its economic benefits on a communal level remain a far cry from those needed to provide wider local economic development.

An important social concept that has historically helped organise life under uncertain living conditions in South Africa is that of Ubuntu. While it is not easily explained in terms of Western societal concepts, Ubuntu has been described as a belief that individual well-being relies on reciprocal trust, and respect among 
community members. Its core idea is that people share responsibility for each other. In other words, it 'highlights the essential unity of humanity and emphasizes the importance of constantly referring to the principles of empathy, sharing and cooperation to resolve common problems' (Murithi 2006:25). The emphasis on sharing aligns itself well with using small business development for wider communal benefits. However, upon closer observation, this is not necessarily the case in the townships. To understand this, it is necessary to appreciate that in the townships society Ubuntu co-exists with the concept of Umona, which is best translated as 'envy' or 'jealousy'. It is related to a fear people have for retribution if they do not share their wealth through Ubuntu. People do not adhere to Ubuntu only out of a sense of duty, but also because they fear retribution through Umona if they do not instantly share their profits. Successful persons who do not share are to be 'pulled down' (e.g. through refusal to cooperate, sabotage or witchcraft) in order to maintain the status quo (Bailey 2003:98, Ashforth 2005:70, Steinbrink 2009).

Ubuntu and Umona, in combination with a close-knit society and high levels of social control, have historically ensured safety and a more equal distribution of wealth (Hentschel 2007:299). However, increasingly they are at odds with local economic development through small business growth as it makes owners afraid to invest in their business, even when in the long-term this may lead to greater communal benefits. It should be noted that this situation is not so much a localised cultural concept typical to the townships, but rather one that arises from uncertain living conditions. In fact, similar practices have been observed in other economically insecure locations (Meagher 2004, Mottiar \& Tucker 2007). Indeed, similar practices were observed by Bailey (1971:19-20) some time ago, who introduced the term 'cultures of equality' to describe situations in which owners try to ensure that others do not get beyond 'approved levels of mediocrity' and may resort to sabotaging another's success even if it also damages themselves. 
Such practices highlight that small businesses are not one united business community and owners may have very different interests.

\subsection{Fractures within communities and intense competition}

Too often social and business communities in impoverished areas are viewed as discrete, relatively stable and homogeneous, while instead they may be described equally as 'fractured', with strong divisions observable (Meagher 2004, Van der Duim et al. 2006:110). This can be observed in the townships too. Salo (2007:153) points out, invisible 'socio-spatial boundaries criss-cross the apparently continuous geographic unit [the township], dividing it into multiple small communities'. In Langa and Imizamo Yethu small township tourism business owners, for example, differentiate themselves on the basis of political or religious affiliation, ethnicity, business type, generation, and migratory status. Conflicts of interests between different groups lessen the potential beneficial economic impact of the small township tourism business community as a whole.

This is perhaps best exemplified by the situation of small tour operators. While they suffer at the hands of large enterprises from outside of the townships, they themselves are accused of power abuse by owners of other business types. In fact large tour operators from outside of the townships are consistently viewed as the most honest, reliable and best paying by tour guides and are most well-liked by craft workers. Additionally, they are attributed with strongly increasing total visitation numbers to the townships by opening them up for tourists that otherwise might not have opted to come to what still are commonly perceived as a dangerous tourist destinations. These larger enterprises have to comply with relatively strict laws and increasingly seek to narrate themselves as socially responsible. On the other hand small locally owned tour operators operate under less direct scrutiny. Restaurant owners complain that in order to receive business from small tour operators, they have to give extreme discounts to an extent that 
they can barely make a profit. Only restaurants that have collaborative relationships with tour operators and travel agents from outside of the townships receive enough custom with profit margins large enough to enable them to grow the business long-term and start sharing economic benefits with the wider community (Koens 2012).

The use of power within the townships can be observed among all business types though. Tour guides are blamed by visitor attractions and craft workers for abusing their power in order to get more money for themselves; one tour guide even indeed admitted to discouraging tourists from giving tips to visitor attractions and has little interest in supporting craft workers to get a larger tip at the end of a tour. Also, individual accommodation owners, restaurant owners and craft workers have been accused of bullying others out of business. Much of this goes unnoticed by government who lack the resources to engage extensively with local business communities.

Strong competition between owners of the same business type is particularly common in accommodation and catering. Owners have hardly any contact with each other and refuse to cooperate. This is a key problem for newly starting small business owners, two of whom had to go to Soweto township near Johannesburg to discuss their business ideas because they felt unable to do so with small business owners in the Cape Town area. A similar example from the crafts sector is provided by the story of someone who set himself up as an intermediary between freelance tour guides and the local township walking tour guides, who assist them, in the early 2000s. The lack of trust among the township walking tour guides was such that they preferred to pay the craft worker, who lived outside the townships, rather than work together to cut him out and increase their overall income. Tour operators and freelance tour guides are more willing to assist newcomers than others. 
In a different context, Thomas (2007:38) argues that small business owners 'whose prosperity is aligned with the future of a particular area will have a powerful motive for taking an interest in that area's future' and understands this in terms of the concept of local dependence. He refers to the work of Davies who notes that businesses with local roots are more likely feel responsible for and get involved to improve the area they operate in (see also Curran et al. 2000, Miller \& Besser 2003). It is difficult to detect a sense of widespread local dependence, defined this way, in the townships. Instead, most small business owners view their time in the townships as temporary and plan to leave as soon as possible. They have little embedded interest in its well-being and feel little responsibility for the future of other township residents. This means that they lack what Thomas \& Thomas (2005:132) term 'mobilisation capacity'; they do not act collectively and stand up to those from outside the townships or seek institutional assistance to promote collective growth. By way of illustration, two of the most successful small tour operators have actually moved out of the townships to live in the centre of Cape Town for reasons of status and in order to be closer to potential partners. While they regularly return to the townships to ensure they continue to be seen as part of the local community, this is not necessarily where most of their money is spent.

All of these examples highlight how little loyalty there is between different township businesses, as owners use their power to maximise individual profits, rather than seeking common, potentially more lucrative benefits. Division and competition over who controls the market is as apparent inside the confines of the townships as it is outside. The fact that the same tour operators, tour guides and catering business owners who report being abused may also be seen as being similarly self-interested, shows how power relations can 'flow in multiple directions', depending on 'one's place/position within a network of relations' (Cheong \& Miller 2000:375). These issues can seriously hamper local economic 
development but have received very little attention in the literature on township tourism to date.

\subsection{Unequal spread of benefits through social networks}

The distribution of economic benefits through social networks is limited. Interviewees commonly work and share profits only with 'strong ties' (Granovetter 1973) such as family and friends. As a result, the benefits of income stimulated by tourism remain limited to certain groups, for example members of a particular church or friends who moved into the townships from the same region in South African countryside. On this matter it is important to turn to the migratory status of small business owners. On the whole small business owners who were born in the township or relatively wealthy recent migrants are most successful due to having well-established social and business networks and greater financial resources to invest in their businesses. The testimony of tour operators who point out that they only get custom from offices where staff are relatives or close friends is indicative of the many. As one noted: 'There is still a lot of favouritism there. So, whether you've got your brochure there or not doesn't make any difference' (int T05). The small business operators that enjoy strong networks are also most likely to engage with government and work with organisations representing small businesses involved in township tourism, and benefit from both. Foreign migrants on the other hand have great difficulty in negotiating their way into the tight, historically significant, fabric of the local community, as they lack an understanding of historical relations and have to overcome prejudices of community members and other small business owners (Harvey 2011:199). There is also a discernible gender dimension as women have difficulty in getting involved in tourism in tour operation or tour guiding, which are among the most profitable of small tourism businesses. This means that at the moment small business involvement in township tourism amplifies existing economic and power differences between different groups of township residents. 
The danger of unequal wealth distribution between local elites and smaller local actors has been a part of the sustainable tourism discourse for some time now (Mowforth \& Munt 2003, Akama \& Kieti 2007). Unequal wealth distribution within local communities through tourism development has received less attention (Mottiar \& Tucker 2007, with notable exceptions, e.g. Dixey 2008). However, an unfettered focus on small business development, without an appreciation of the ways in which the benefits are distributed, runs the risk of reinforcing the advantages of an already relatively advantaged minority. 


\section{Conclusion}

Experiences from Langa and Imizamo Yethu confirm the work of some other commentators who have argued that local economic development is not inevitably widespread simply by involving local small businesses (Briedenhann \& Ramchander 2006, Nel et al. 2009, Rogerson \& Rogerson 2010). The research reported in this paper has shed light on the dynamics which explain the limitations of promoting small businesses for local economic development in the context of developing economies. Supporting the creation of new small businesses without paying attention to how they will gain market access severely limits local economic development. Within the cases of township tourism examined as part of this project, up to $90 \%$ of the market is serviced by a small number of actors, almost all of whom operate from outside of the townships. In this situation an oversupply of unregulated small businesses leads to owners competing heavily against each other and this is likely to worsen if more businesses are created. To an extent, the findings confirm the proposition that an emphasis on the integration of small businesses into mainstream tourism is required if the net benefits of tourism are to benefit the 'the poor' (Meyer 2007, Mitchell et al. 2007:4).

A lack of market access is not the only factor that impedes the potential contribution of tourism to economic development in townships. Perhaps more importantly is the influence of highly uncertain living and business conditions and the diversity of township communities. Those communities with little trust and limited government support have created a context of 'destructive uncertainty' (Wood 2003:468), in which most small township tourism business owners focus on subsistence rather than business growth. The perceived need to share profits directly, rather than invest in the business, in a context of uncertain living conditions and 'cultures of equality' (Bailey 1971:19-20), can seriously hamper the long-term benefits of small business development. 
There was no evidence in this study to suggest that the owners of economically successful businesses do more to support their peers than their larger counterparts from outside of the townships. The assumption that small business owners are more likely to support local economic development by spending most of their profits locally is also challenged. Due to a lack of sense of place, successful small business owners tend to leave the townships as soon as they are able to do so. Thus, while tourism, with its low entry thresholds, provides opportunities for weaker or marginalised groups in society (UNWTO 2006, UNWTO \& UN Women 2011), the greatest economic gains in Langa and Imizamo Yethu remain limited to a relatively small number already privileged, predominantly male small business owners, who are most likely to spend their income within their limited social networks. Businesses operated primarily by marginalised groups provide much less economic gain. This confirms earlier work that questions the extent to which weaker groups in impoverished communities benefit from tourism (Chok et al. 2007, Tucker \& Boonabaana 2011). Nevertheless, the foregoing analysis does not imply that small business development as part of township tourism cannot be beneficial. Instead, it suggests that policy-makers should recognise the socioeconomic complexity of townships and consider their interventions accordingly. 


\section{References}

Akama, JS \& Kieti, D, 2007. Tourism and Socio-economic Development in Developing Countries: A Case Study of Mombasa Resort in Kenya. Journal of Sustainable Tourism, 15 (6), 735-48.

Ashforth, A, 2005. Witchcraft, violence, and democracy in South Africa. University of Chicago Press.

Bah, A. \& Goodwin, H, 2003. Improving Access for the Informal Sector to Tourism in The Gambia. London: Pro-Poor Tourism Partnership.

Bailey, B, 2003. The plays of miracle \& wonder: bewitching visions and primal highjinx from the South African stage. Cape Town: Double Storey Books.

Bailey, FG (ed) 1971. Gifts and Poison - The Politics of Reputation. Oxford: Basil Blackwell.

Binns, T. \& Nel, E, 2002. Tourism as a local development strategy in South Africa. Geographical Journal, 168 (3), 235-47.

Booyens, I. \& Visser, G, 2010. Tourism SMME Development on the Urban Fringe: The Case of Parys, South Africa. Urban Forum, 21 (4), 367-85.

Briedenhann, J. \& Ramchander, P, 2006. Township Tourism: Blessing or Blight? The Case of Soweto South Africa. In: Smith, MK \& Robinson, M (eds) Cultural Tourism in a Changing World: Politics, Participation and (Re)presentation. Clevedon: Channel View Publications, 124-42.

Britton, SG, 1982. The political economy of tourism in the Third World. Annals of Tourism Research, 9 (3), 331-58.

Britton, SG, 1987. Tourism in small developing countries. In: Britton, SG \& Clarke, WC (eds) Ambiguous Alternative: Tourism in Small Developing Countries. Suva: University of South Pacific, 167-194.

Brohman, J, 1996. New directions in tourism for Third World development. Annals of Tourism Research, 23, 48-70.

Burns, PM, 2004. Tourism Planning: A Third Way? Annals of Tourism Research, 31 (1), 24-43.

Cheong, SM. \& Miller, M.L, 2000. Power and tourism: A Foucauldian observation. Annals of Tourism Research, 27 (2), 371-90.

Cheru, F, 2001. Overcoming apartheid's legacy: The ascendancy of neoliberalism in South Africa's anti-poverty strategy. Third World Quarterly, 22 (4), 505-27.

Chok, S, Macbeth, J, \& Warren, C, 2007. Tourism as a Tool for Poverty Alleviation: A Critical Analysis of 'Pro-Poor Tourism' and Implications for Sustainability. Current Issues in Tourism, 10 (2), 144-65.

City of Cape Town, 2013. Census 2011. Cape Town: Strategic Development Information and GIS Department (SDI\&GIS), City of Cape Town.

Curran, J, Rutherfoord, R, \& Smith, SL, 2000. Is There a Local Business Community? Explaining the non-participation of small business in local economic development. Local Economy (Routledge), 15 (2), 128-43. 
Dahles, H. \& Bras, K, 1999. Tourism and Small Entrepreneurs: Development, National Policy, and Entrepreneurial Culture: Indonesian Cases. New York: Cognizant Communication.

Dierwechter, Y, 2006. Geographical Limitations of Neo-liberalism: Urban Planning and the Occluded Territoriality of Informal Survival in African Cape Town. Space and Polity, 10, 243-62.

Dixey, LM, 2008. The Unsustainability of Community Tourism Donor Projects: Lessons from Zambia. In: Spenceley, A (ed) Responsible tourism: Critical issues for conservation and development. London: Earthscan, 323-43.

Duval, DT, 1998. Alternative tourism on St Vincent. Caribbean Geography: A Journal of Geography for the Region, 9 (1), 44-57.

Granovetter, M, 1973. The strength of weak ties. American Journal of Sociology, 78 (6), 1360-80.

Hampton, MP, 1998. Backpacker Tourism and Economic Development. Annals of Tourism Research, 25 (3), 639-60.

Harvey, RA, 2011. Tourism is everyone's business: the participants and places of township tourism in Cape Town, South Africa. PhD thesis. University of Florida, Gainesville.

Helmsing, AHJ, 2003. Local economic development: new generations of actors, policies and instruments for Africa. Public Administration and Development, 23 (1), 67-76.

Hentschel, C, 2007. Making (In)Visible: CCTV, 'Living Cameras,' and Their Objects in a Post-Apartheid Metropolis. International Criminal Justice Review, 17 (4), 289-303.

Jaafar, M, Abdul-Aziz, AR, Maideen, SA, \& Mohd, SZ, 2011. Entrepreneurship in the tourism industry: Issues in developing countries. International Journal of Hospitality Management, 30 (4), 827-35.

Kirsten, M. \& Rogerson, CM, 2002. Tourism, business linkages and small enterprise development in South Africa. Development Southern Africa, 19 (1), 29-60.

Koens, JF, Miranda, MA, \& Dieperink, C, 2009. Ecotourism as a development strategy; experiences from Costa Rica. Environment, Development and Sustainability, 11 (6), 1225-37.

Koens, K, 2012. Competition, Cooperation And Collaboration; Business Relations And Power In Township Tourism. In: Frenzel, F, Koens, K. \& Steinbrink, M. (eds) Slum Tourism: Poverty, Power and Ethics. London: Routledge, $83-$ 100.

Koens, K, 2014. Small businesses and township tourism around Cape Town. PhD thesis. Leeds Metropolitan University, Leeds.

Meagher, K, 2004. Identity Economics: Informal Manufacturing and Social Networks in South-eastern Nigeria. PhD thesis. University of Oxford, Oxford.

Meyer, D, 2007. Pro-Poor Tourism: From Leakages to Linkages. A Conceptual Framework for Creating Linkages between the Accommodation Sector and 
'Poor' Neighbouring Communities. Current Issues in Tourism, 10 (6), 55883.

Miller, NJ. \& Besser, TL, 2003. Investigating small community influences on US entrepreneurs' goals, business strategies and success. The International Journal of Entrepreneurship and Innovation, 4 (3), 149-61.

Milne, S, 1998. Tourism and sustainable development: exploring the global-local nexus. In: Hall, CM \& Lew, AA (eds) Sustainable tourism: a geographical perspective. Harlow: Prentice Hall, 35-48.

Mitchell, J, Ashley, C, \& Jones, G, 2007. Pathways to Prosperity - How can tourism reduce poverty: a review of pathways, evidence and methods. Washington D.C.: World Bank / ODI.

Mottiar, Z. \& Tucker, H, 2007. Webs of Power: Multiple Ownership in Tourism Destinations. Current Issues in Tourism, 10 (4), 279-95.

Mowforth, M. \& Munt, I, 2003. Tourism and sustainability: development and new tourism in the Third World. London: Routledge.

Murithi, T, 2006. Practical peacemaking wisdom from Africa: Reflections on Ubuntu. Journal of Pan African Studies, 1 (4), 25-37.

Nel, E, Binns, T, \& Bek, D, 2009. Misplaced Expectations? The Experience of Applied Local Economic Development in Post-Apartheid South Africa. Local Economy, 24 (3), 224-37.

Nel, E \& Rogerson, CM (eds) 2005. Local Economic Development in the Development World: The Experience of Southern Africa. New Brunswick: Transaction Publishers.

Peet, R, 2002. Ideology, Discourse, and the Geography of Hegemony: From Socialist to Neoliberal Development in Postapartheid South Africa. Antipode, 34 (1), 54-84.

Pirie, G, 2007. Urban Tourism in Cape Town. In: Rogerson, CM \& Visser, G (eds) Urban Tourism in the Developing World: The South African Experience. London: Transaction Publishers, 223-45.

Poon, A, 1990. Flexible specialization and small size: The case of Caribbean tourism. World Development, 18, 109-23.

Rogerson, CM, 2004a. Urban tourism and small tourism enterprise development in Johannesburg: The case of township tourism. Geojournal, 60 (3), 249-57.

Rogerson, CM, 2004b. Transforming the South African tourism industry: The emerging black-owned bed and breakfast economy. Geojournal, 60 (3), 273-81.

Rogerson, CM, 2004c. The impact of the South African government's SMME programmes: a ten-year review (1994-2003). Development Southern Africa, 21 (5), 765-84.

Rogerson, CM, 2005. Unpacking tourism SMMEs in South Africa: structure, support needs and policy response. Development Southern Africa, 22 (5), 623-42.

Rogerson CM 2008a. Shared growth and urban tourism: evidence from Soweto, Urban Forum, 19, 395-411. 
Rogerson CM 2008b, Shared growth and tourism small firm development in South Africa. Tourism Recreation Research, 33 (3), 333-338.

Rogerson, CM, 2012. Niche Tourism Policy and Planning: The South African Experience. Tourism Review International, 15 (1-2), 199-211.

Rogerson, CM. \& Rogerson, JM, 2010. Local economic development in Africa: Global context and research directions. Development Southern Africa, 27 (4), 465-80.

Rolfe, R, Woodward, D, Ligthelm, A, \& Guimarães, P, 2010. The Viability of Informal Micro-Enterprise in South Africa. Presented at the Entrepreneurship in Africa - Whitman School of Management, Syracuse University, New York.

Saarinen, J, Rogerson, C, \& Manwa, H, 2011. Tourism and Millennium Development Goals: tourism for global development? Current Issues in Tourism, 14 (3), 201-3.

Salo, E, 2007. Mans is ma soe: Ganging practices in Manenberg, South Africa and the ideologies of masculinity, gender and generational relations. In: Bay, EG \& Donham, DL (eds) States of Violence: Politics, Youth, and Memory in Contemporary Africa. Charlottesville: University of Virginia Press, 148-75.

Scheyvens, R, 2007. Exploring the Tourism-Poverty Nexus. Current Issues in Tourism, 10 (2-3), 231-54.

Scheyvens, R, 2008. On The Beach: Small-Scale tourism in Samoa. In: Connell, J \& Rugendyke, B (eds) Tourism at the Grassroots: Villagers and Visitors in the Asia-Pacific. London: Routledge, 131-47.

Scheyvens, R. \& Russell, M, 2012. Tourism and poverty alleviation in Fiji: comparing the impacts of small- and large-scale tourism enterprises. Journal of Sustainable Tourism, 20 (3), 417-36.

Steinbrink, M, 2009. Leben zwischen Land und Stadt: Migration, Translokalität und Verwundbarkeit in Südafrika. Osnabruck: VS Verlag.

Thomas, R, 2007. Tourism partnerships and small firms: Power, participation and partition. The International Journal of Entrepreneurship and Innovation, 8, 37-43.

Thomas, R, Shaw, G, \& Page, SJ, 2011. Understanding small firms in tourism: A perspective on research trends and challenges. Tourism Management, 32 (5), 963-76.

Thomas, R. \& Thomas, H, 2005. Understanding Tourism Policy-Making in Urban Areas, with Particular Reference to Small Firms. Tourism Geographies, 7 (2), 121-37.

Thomlinson, E. \& Getz, D, 1996. The Question of Scale in Ecotourism : Case Study of Two Small Ecotour Operators in the Mundo Maya Region of Central America. Journal of Sustainable Tourism, 4 (4), 183-200.

Tucker, H. \& Boonabaana, B, 2011. A critical analysis of tourism, gender and poverty reduction. Journal of Sustainable Tourism, 20 (3), 437-55.

UNWTO, 2006. Tourism and Least Developed Countries: A Sustainable Opportunity to Reduce Poverty. Madrid: United Nations World Tourism Organization. 
UNWTO \& UN Women, 2011. Global Report on Women in Tourism 2010. Madrid, New York: UNWTO, UN Women.

Van der Duim, VR. \& Caalders, J, 2008. Tourism Chains and Pro-Poor Tourism Development: An Actor-Network Analysis of a Pilot Project in Costa Rica. Current Issues in Tourism, 11, 1-17.

Van der Duim, VR, Peters, KBM, \& Akama, J, 2006. Politics, Power and Play: The Shifting Contexts of Cultural Tourism. In: Robinson, M \& Smith, M (eds) Cultural Tourism in a changing World: Politics, participation and (re) presentation. Clevedon: Channel View Publications, 89-104.

Wahnschafft, R, 1982. Formal and informal tourism sectors: A case of Pattaya, Thailand. Annals of Tourism Research, 9, 429-51.

Wilson, D, 1997. Paradoxes of tourism in Goa. Annals of Tourism Research, 24, 5275.

Wood, G, 2003. Staying Secure, Staying Poor: The 'Faustian Bargain'. World Development, 31 (3), 455-71.

Zhao, W. \& Brent Ritchie, JR, 2007. Tourism and Poverty alleviation: An integrative Research Framework. Current Issues in Tourism, 10 (2-3), 119-25. 